\title{
Primary immunodeficiencies associated with eosinophilia
}

\author{
Behdad Navabi ${ }^{{ }^{* *}}$ and Julia Elizabeth Mainwaring Upton ${ }^{2}$
}

\begin{abstract}
Background: Eosinophilia is not an uncommon clinical finding. However, diagnosis of its cause can be a dilemma once common culprits, namely infection, allergy and reactive causes are excluded. Primary immunodeficiency disorders (PID) are among known differentials of eosinophilia. However, the list of PIDs typically reported with eosinophilia is small and the literature lacks an inclusive list of PIDs which have been reported with eosinophilia. This motivated us to review the literature for all PIDs which have been described to have elevated eosinophils as this may contribute to an earlier diagnosis of PID and further the understanding of eosinophilia.

Methods: A retrospective PubMed, and Google Scholar search using the terms "eosinophilia" and "every individual PID" as classified by Expert Committee of the International Union of Immunological Societies with the limit of the English language was performed. Results were assessed to capture case(s) which reported eosinophilia in the context of PID conditions. Absolute eosinophil counts (AEC) were retrieved from manuscripts whenever reported.

Results: In addition to the typical PID conditions described with eosinophilia, we document that MHC class II deficiency, CD3y deficiency, STAT1 deficiency (AD form), Kostmann disease, cyclic neutropenia, TCRa deficiency, Papillon-Lefevre syndrome, CD40 deficiency, CD40L deficiency, anhidrotic ectodermal dysplasia with immune deficiency, ataxia-telangiectasia, common variable immunodeficiency disorders (CVID), Blau syndrome, CARD9 deficiency, neonatal onset multisystem inflammatory disease or chronic infantile neurologic cutaneous and articular syndrome (NOMID/CINCA), chronic granulomatous disease, MALT1 deficiency and Roifman syndrome have been noted to have elevated eosinophils. Severe eosinophilia $\left(>5.0 \times 10^{9} / \mathrm{L}\right)$ was reported in Omenn syndrome, Wiskott Aldrich syndrome, ADA deficiency, autoimmune lymphoproliferative syndrome, immunodysregulation polyendocrinopathy enteropathy X-linked, STAT3 deficiency, DOCK8 deficiency, CD40 deficiency, MHC II deficiency, Kostmann disease, Papillon-Lefevre syndrome, and CVID.
\end{abstract}

Conclusions: This literature review shows that there is an extensive list of PIDs which have been reported with eosinophilia. This list helps clinicians to consider an extended differential diagnoses when tasked with exclusion of PID as a cause for eosinophilia.

Keywords: Eosinophilia, Primary immunodeficiency disorders, Severe eosinophilia, Eosinophilia differentials

\section{Background}

Eosinophils are primarily tissue-dwelling cells found in relatively low numbers within the circulation (less than $400 / \mathrm{mm}^{3}$ ) [1-3]. Eosinophilia can be secondary to varied conditions as recently reviewed by Curtis et al. [2], and can be classified based on absolute eosinophil

\footnotetext{
*Correspondence: behdad.navabi@sickkids.ca

1 Department of Paediatrics, The Hospital for Sick Children, University

of Toronto, 555 University Avenue, Toronto, ON M5G-1X8, Canada

Full list of author information is available at the end of the article
}

count (AEC) as mild: $0.5-1.5 \times 10^{9} / \mathrm{L}$, moderate: $1.5-$ $5.0 \times 10^{9} / \mathrm{L}$, or severe: $>5.0 \times 10^{9} / \mathrm{L}[4]$.

Primary immunodeficiency is a known differential diagnosis of eosinophilia that needs to be ruled out, particularly in pediatrics, when more common differentials such as infection, allergy and reactive causes are excluded [2, 5-7]. Eosinophilia in association with PIDs is well known; however, few PIDs are typically described in association with eosinophilia [5-9]. Most recent reviews of PIDs with eosinophilia include Wiskott 
Aldrich syndrome (WAS), hyper IgE syndromes (HIES), Omenn syndrome (OS), immunodysregulation polyendocrinopathy enteropathy X-linked (IPEX) syndrome, and Netherton's syndrome. Moreover, ZAP70 deficiency, autoimmune lymphoproliferative syndrome (ALPS), selective IgA deficiency, and adenosine deaminase (ADA) deficiency have also appeared in differential diagnosis of eosinophilia.

Knowledge of the PIDs reported to have eosinophilia could assist clinicians assessing patients with eosinophilia when PID is considered. Given the current small list of PIDs reported with eosinophilia, we considered if a more comprehensive list could be generated by reviewing the literature. This review aimed to primarily capture PIDs reported with eosinophilia, and secondarily determine degree of eosinophilia where possible. Finally, some possible mechanisms driving eosinophilia in PID are highlighted.

\section{Methods}

A review of the literature was undertaken to generate a list of PIDs reported with eosinophilia and to attempt to determine the degree of eosinophilia. PubMed and subsequently Google Scholar searches with English language filter were performed using the terms "eosinophilia" AND "every individual PID" as classified by Expert Committee of the International Union of Immunological Societies (IUIS) [9]. Abstracts of the PubMed results, and the title and the text of Google Scholar results were reviewed to find any case reports, case series or review articles, in which case eosinophilia and absolute eosinophil counts (AEC) were sought in the manuscript. Moreover, references of review articles and case series were assessed for any additional cases. This led to inclusion of CHD7 and CARD11 as genetic defects of OS [10,11], and PGM3 deficiency [6, 12]. Lastly, Roifman syndrome $[13,14]$ and MALT1 deficiency [15] were included due to authors' knowledge that they have been reported with eosinophilia.

As the primary goal was to capture the PIDs reported with eosinophilia we did not cite every article which describes eosinophilia. Once a condition was captured, we aimed to cite references with reported AEC but not necessarily all references which described eosinophilia for that condition. No minimum number of reports was required to be included in this review.

\section{Results}

Here, PIDs reported in association with eosinophilia are briefly described. The cumulative range of eosinophilia in each condition and the retrieved AECs with their sources are respectively compiled in Table 1 and Additional file 1 :
Table S1. Online Mendelian Inheritance in Man (OMIM) numbers are provided in brackets after each condition.

\section{Combined immunodeficiencies \\ ADA deficiency (\#102700)}

ADA deficiency leads to accumulation of toxic deoxyATP within cells and immunodeficiency [16-18]. Late-onset ADA deficiency has been reported with eosinophilia [18-22].

\section{CD3y deficiency (\#186740)}

CD3 $\gamma$ deficiency, unlike CD3 $\delta$, $\varepsilon$, and $\zeta$ deficiency, tends to present as combined immunodeficiency with variable onset [23, 24]. Autoimmunity, normal protein-specific antibody responses, high IgE, eosinophilia, and atopic eczema have been described in CD3 $\gamma$ deficiency [23-25]

\section{ZAP70 deficiency (\#269840)}

ZAP70 is a central signalling molecule in thymic selection of the CD4 and CD8 lineages [26, 27]. Patients may present with an atopic dermatitis-like skin rash, eosinophilia and elevated IgE [28-30].

\section{MHC class II deficiency (\#209920)}

MHC class II plays a pivotal role in CD4 T cell development and function [31, 32]. Reduced CD4+T cells, hypogammaglobulinemia, and an inability to mount immune responses are among the immunologic characteristics [32]. Eosinophilia has been reported in few cases [31,33].

\section{TCRa deficiency (\#615387)}

TRAC mutation interferes with a functional TCR $\alpha \beta$ receptor [34-36]. Eosinophilia, frequently recurring infections, failure to thrive, autoimmunity, eczema, organomegaly, and elevated IgE have been reported [37].

\section{MALT1 deficiency (\#604860)}

MALT1 is a regulator of NF- $\mathrm{KB}$ signalling. Normal to very low $B$ cells, normal immunoglobulin with chronically elevated IgE are described [38, 39]. Eosinophilia was noted in this condition [15].

\section{Omenn syndrome (OS; \#603554)}

OS is characterized by erythroderma, lymphadenopathy, eosinophilia, and profound immunodeficiency in infants $[11,40,41]$. Hepatosplenomegaly, hypogammaglobulinemia with elevated IgE are among other features [11, 42]. The OS genetic defects reported to be associated with eosinophilia include: RAG1/RAG2, ARTEMIS, ADA, CHD7, RMRP [43, 44], LIG4, IL-2RG, IL7RA, and CARD11 [10]. Defects in $A K 2$ were not included here as the only OS due to $A K 2$ defect did not comment on eosinophilia [45]. 
Table 1 Primary immunodeficiency disorders associated with eosinophilia

\begin{tabular}{|c|c|c|c|c|}
\hline PID & Genetic defect/subtype (s) & Functional defect & Inheritance & AEC range $\left(\times 10^{9} / L\right)^{b}$ \\
\hline \multicolumn{5}{|c|}{ Combined immunodeficiencies } \\
\hline ADA Deficiency & Late onset ADA & Elevated lymphotoxic metabolites & $A R$ & $0.8-4.7$ \\
\hline ZAP70 deficiency ${ }^{\mathrm{a}}$ & ZAP70 & Intracellular signaling abnormality & $A R$ & 9.5 \\
\hline CD3 $\gamma$ deficiency ${ }^{a}$ & CD3G & T-cell receptor expression defect & $A R$ & $0.2-0.7$ \\
\hline MHC II deficiency ${ }^{a}$ & RFXANK & Impaired antigen presentation by APCs & $A R$ & $3-10$ \\
\hline TCR a deficiency & TRAC & T-cell receptor generation & $A R$ & $0.08-2.5$ \\
\hline MALT1 deficiency & MALT1 & NF-kB activation failure & $A R$ & Not specified \\
\hline \multirow[t]{10}{*}{$\mathrm{OS}^{\mathrm{a}}$} & RAG 1/2 & T-cell receptor generation abnormality & $A R$ & $0.1-21.8$ \\
\hline & ILTRA & Defect in IL-7 receptor a chain & $A R$ & 6.49 \\
\hline & $I L-2 R G$ & Cytokine receptor signaling abnormality & $A R$ & 15.56 \\
\hline & $22 q 11.2$ & DiGeorge syndrome & $A D$ & $1.36->15$ \\
\hline & CHD7 & Chromatin organization defects & $A R$ & $1.3-4.1$ \\
\hline & LIG4 & DNA DSB repair defect & $A R$ & 2.12 \\
\hline & $A D A$ & Elevated lymphotoxic metabolites & $A R$ & $0.85-1.73$ \\
\hline & $R M R P$ & Mitochondrial RNA processing defects & $A R$ & Not specified \\
\hline & CARD11 & TCR/BCR induced NF-kB activation failure & $A R$ & Not specified \\
\hline & ARTEMIS & DNA repair defect & $A R$ & Not specified \\
\hline \multicolumn{5}{|c|}{ Combined immunodeficiencies with associated or syndromic features } \\
\hline Ataxia-Telangiectasia & ATM & DNA break repair defect & $A R$ & Not specified \\
\hline WAS $^{\mathrm{a}}$ & WAS & Actin cytoskeleton abnormality & AR & $0-8.32$ \\
\hline NS & SPINK5 & Pro-Th2 and stratum corneum detachment & $A R$ & Not specified \\
\hline \multirow[t]{3}{*}{ HIES } & STAT3 ${ }^{\mathrm{a}}$ & Intracellular signaling abnormality & $A D$ & $0.029-54.81$ \\
\hline & Tyk2 & Cytokine signaling abnormality & $A R$ & $0.29-0.8$ \\
\hline & $D O C K 8^{\mathrm{a}}$ & Cytoskeletal organization defects & $A R$ & $0.245-37.88$ \\
\hline \multicolumn{5}{|c|}{ Predominantly antibody deficiencies } \\
\hline CVID & Unknown & Unknown & Variable & $0.385-1.562$ \\
\hline CD40L deficiency & CD4OL & Defects in lg isotype switching & $X L$ & $0.5-1.5$ \\
\hline CD40 deficiency ${ }^{\mathrm{a}}$ & CD40 & Defects in lg isotype switching & $A R$ & $0.8-13.5$ \\
\hline Selective IgA deficienc) & & Unknown & & 0.672 \\
\hline \multicolumn{5}{|c|}{ Diseases of immune dysregulation } \\
\hline IPEX & FOXP3 & Dysfunction of regulatory Tcells & $X L$ & $0.236-8.423$ \\
\hline \multirow[t]{2}{*}{ ALPS $^{a}$} & TNFRSF6 & Failure of apoptosis & $A D$ & $1.33-35.46$ \\
\hline & Other ${ }^{c}$ & Failure of apoptosis & & Not specified \\
\hline \multicolumn{5}{|c|}{ Congenital defects of phagocyte number or function or both } \\
\hline Kostmann disease & HAX1 & Control of apoptosis & $A R$ & $0.09-1.30$ \\
\hline Cyclic neutropenia & ELANE & "Gain-of-function" in the neutrophil granule & $A D$ & Not specified \\
\hline STAT1 deficiency ${ }^{\mathrm{a}}$ & STAT1 & IFN- $\gamma$ signalling defect & $A D$ & 11.1 \\
\hline PLS & FPR1 & Defective chemotaxis of PMNs & $A R$ & $0.96-2.156$ \\
\hline CGD & $C Y B B$ & Neutrophil oxidative burst deficiency & $X L$ & 0.786 \\
\hline \multicolumn{5}{|c|}{ Defects of innate immunity } \\
\hline EDA-ID & NEMO & Failure of NEMO-induced NF-KB activation & $X L$ & 1.45 \\
\hline CARD9 deficiency & CARD9 & Selective defect in defense against fungal infection & $A R$ & Not specified \\
\hline \multicolumn{5}{|c|}{ Autoinflammatory disorders } \\
\hline NOMID/CINCA & CIAS1 & Defect in regulation of inflammation and apoptosis & $A D$ & $0.728-3.441$ \\
\hline Blau syndrome & NOD2 & NF-KB activation causing excess inflammatory cytokine & $A D$ & Not specified \\
\hline \multicolumn{5}{|l|}{ Not classified by IUIS } \\
\hline PGM3 deficiency & PGM3 & Possibly signalling defects & $A R$ & $0-3.6$ \\
\hline Roifman syndrome & RNU4ATAC & Disrupted minor intron splicing & $A R$ & Not specified \\
\hline
\end{tabular}

a Conditions with severe eosinophilia

b The absolute eosinophil count(s) with further details and source references in Additional file 1: Table S1

c TNFSF6 or CASP8 or CAS10 
DiGeorge syndrome has also been rarely reported to present with OS and eosinophilia [46, 47].

\section{Combined immunodeficiencies with associated or syndromic features \\ Wiskott-Aldrich syndrome (WAS; \#301000)}

WAS classically presents with the triad of thrombocytopenia, eczema and recurrent infections [48, 49]. It is associated with elevated IgE and IgA, inability to generate antibody against polysaccharide antigens, and eosinophilia [49-51]. A review of 154 patients found that $31 \%$ had eosinophilia [50].

\section{Ataxia-telangiectasia (\#208900)}

Ataxia-telangiectasia is characterized by progressive neurological abnormalities, radiosensitivity, and variable immunodeficiency [52]. Laboratory findings often include hypogammaglobulinemia, lymphopenia, and reversed CD4/CD8 ratio [52]; eosinophilia has also been reported in few cases $[53,54]$.

\section{Hyper-IgE syndromes (HIES)}

AD-HIES (Job's syndrome; \#147060) AD-HIES is distinguished by its connective tissue, skeletal system, and dentition involvements in addition to recurrent infections, atopic dermatitis, elevated IgE, and eosinophilia [55]. STAT3 is the key to signal transduction of many cytokines, and memory $\mathrm{B}$ cells generation and mutations are causative [56-58]. Eosinophilia is noted in $80 \%$ of AD-HIES patients [59]. A gain of function of STAT3 (p.Y640F) has recently been identified in lymphocytic variant of hypereosinophilic syndrome [60]. Therefore STAT3 appears to have an important role in eosinophil regulation.

DOCK8 deficiency (\#243700) DOCK8 deficiency accounts for the majority of AR-HIES [61-64] and is characterized by extensive cutaneous viral infections (herpes simplex, varicella zoster, human papillomavirus, and molluscum contagiosum), central nervous system (CNS) complications, elevated IgE, and eosinophilia [61, 65, 66].

Tyk2 deficiency (\#611521) To date there have been few reported cases of Tyk2 deficiency $[67,68]$. Only the first patient had features of HIES including atopic dermatitis, eosinophilia, and high serum IgE levels [69]. However, mycobacterial and/or viral infections have been the most common phenotype among these patients $[67,68]$. Eosinophilia is described in 2 of 8 total reported cases $[68,69]$.

\section{Comel-Netherton syndrome (NS; \#256500)}

NS presents with atopic manifestations, an ichthyotic skin condition, and bamboo hair shaft defects due to SPINK5 mutations [70, 71]. Elevated IgE and eosinophilia are frequently seen $[6,70-74]$. Smith et al. showed eosinophilia in 7 out of 44 patients with NS [75].

\section{Predominantly antibody deficiencies Common variable immunodeficiency disorders (CVID)}

CVID is one of the more common immunodeficiencies with variable phenotypes mostly presents by recurrent infections, and low IgG and IgA and/or IgM [9, 76, 77]. There are few cases of CVID with eosinophilia [78-80]; however, it is difficult to determine prevalence of eosinophilia in CVID.

\section{CD40 ligand (CD40L) deficiency (\#300386)}

CD40L deficiency characterized by recurrent infections, low IgG and IgA, and normal to increased IgM [81]. Eosinophilia has been described [82-84], and in one patient it was reported along with Cryptosporidium parvum and Cryptococcus neoformans infections [84].

\section{CD40 deficiency (\#109535)}

CD40 deficiency is clinically indistinguishable from CD40L deficiency [85]. Eosinophilia has been described with Cryptosporidium infection [86, 87].

\section{Selective IgA deficiency (\#137100)}

IgA deficiency is usually asymptomatic and characterized by a decreased or absent level of serum IgA with normal IgG and IgM [9, 88, 89]. It is considered on differential diagnoses of secondary eosinophilia $[8,90,91]$.

\section{Diseases of immune dysregulation Immunodysregulation polyendocrinopathy enteropathy X-linked (IPEX; \#304790)}

IPEX is a regulatory $\mathrm{T}$ (Treg) cell defect typically presents early in life $[92,93]$. T cells are quantitatively normal with normal proliferative responses to mitogens and antigens; however, Treg cells are markedly reduced or absent [9496]. High IgE and eosinophilia are frequently reported in IPEX patients [92, 97, 98].

\section{ALPS-FAS (\#601859)}

ALPS-FAS is a disorder of lymphocyte homeostasis due to FAS receptor protein [99, 100]. Pathognomonic elevated double-negative $\mathrm{T}$ lymphocytes $\left(\mathrm{TCR} \alpha \beta^{+} \mathrm{CD} 4^{-} \mathrm{CD} 8^{-}\right.$) [101-103], anemia, thrombocytopenia, and eosinophilia are among the laboratory findings [99, 100, 104, 105]. In a report of 68 patients with ALPS, 11 patients were found to have eosinophilia [104].

\section{Congenital defects of phagocyte number or function or both} SCN3 (Kostmann disease; \#610738)

Kostmann disease typically presents with recurrent bacterial infections from early infancy, severe non-cyclic 
neutropenia, maturation arrest of myeloid differentiation, and compensatory monocytosis and eosinophilia [106109]. Eosinophilia is considered to be a component of the classic presentation.

\section{Cyclic neutropenia (\#162800)}

Cyclic neutropenia presents with recurrent fever, oral ulcers, recurrent oropharyngeal infections and periodic neutropenia [106]. In a review by Lang et al. eosinophilia was seen in $8.6 \%$ of pediatric and $3.7 \%$ of adult cases [110].

\section{Papillon-Lefevre syndrome (PLS; \#245000)}

PLS is characterized by diffuse palmoplantar hyperkeratosis, rapid progressive periodontitis involving both deciduous and permanent dentition [111, 112]. Laboratory findings include decreased peripheral CD3 and CD4, defective burst test, as well as few cases of eosinophilia [111-113].

\section{X-linked chronic granulomatous disease (CGD; \#306400)}

CGD is characterized by susceptibility to catalase-positive bacterial and fungal infections [114]. One CGD patient with mild eosinophilia despite taking prednisone every other day for eosinophilic colitis was reported [115]. There have also been reports of eosinophilia and eosinophilic inflammatory conditions in CGD patients including eosinophilic gastroenteritis and eosinophilic cystitis $[115,116]$.

\section{STAT1 deficiency (AD form) (\#600555)}

Partial STAT1 deficiency can present as Mendelian Susceptibility to Mycobacterial Disease due to IFN- $\gamma$ signaling defects [117-119]. There is one case with persistent leukocytosis and hypereosinophilia in a 2 month of age child who later was diagnosed as STAT1 deficiency [118].

\section{Defects of innate immunity \\ Anhidrotic ectodermal dysplasia-immune deficiency (EDA-ID; NEMO deficiency; \#300248)}

NEMO deficiency has been reported in various diseases including ectodermal dysplasia, incontinentia pigment, and severe life threatening pyogenic and mycobacterial infections [120-122]. Most patients have low serum IgG levels, with variable levels of other immunoglobulin isotypes [120, 123]; eosinophilia has also been reported [122-125].

\section{CARD9 deficiency (\#212050)}

CARD9 is a cytosolic adaptor protein involved in differentiation of naïve T cells to TH17 [126]. Its defects are associated with recurrent Candida infections as well as susceptibility to deep dermatophytosis [126, 127]. Eosinophilia and elevated IgE level have been reported [127-129].

\section{Autoinflammatory disorders \\ Neonatal onset multisystem inflammatory disease (NOMID) or chronic infantile neurologic cutaneous and articular syndrome (NOMID/CINCA; \#607115)}

NOMID/CINCA is characterized by the triad of rash, CNS involvements and arthropathy. Leukocytosis, thrombocytosis and eosinophilia, as well as elevated acute-phase reactants are among the laboratory findings [130-132].

\section{Blau syndrome (BS; \#186580)}

$\mathrm{BS}$ is a non-caseating granulomatous disease characterized by triad of uveitis, arthritis, and dermatitis of varying morphology [133, 134]. Hypercalcemia, hypercalciuria, elevated angiotensin converting enzyme level, leukopenia, and eosinophilia are described laboratory findings [135-139].

\section{Not classified by IUIS \\ PGM3-deficiency}

PGM3 deficiency presents with hyper-IgE-like features, atopy, autoimmunity and neurocognitive impairment [6, 12, 67, 140-142]. PGM3 is involved in posttranslational alterations necessary for functioning of many proteins and lipids [141]. Eosinophilia, inverted CD4/CD8 ratio, and increased IgE level were described [142].

\section{Roifman syndrome}

Roifman syndrome is characterized by bone dysplasia, growth retardation, retinal dystrophy and humoral immunodeficiency $[13,14]$. In the original description of Roifman syndrome 3/4 patients had eosinophilia [13].

\section{Discussion}

Evaluation of possible PID in a patient with eosinophilia Many patients with eosinophilia will be explained by secondary causes such as parasitic infections, allergies, or hematological problems which are well reviewed elsewhere $[2,5-7]$. If PID is being considered as a potential cause of eosinophilia, a wide range of PIDs have been associated with eosinophilia including disorders of Tcell development and signalling, cytokine signalling, cytoskeletal formation, autoimmunity, thymic development, innate immunity, humoral immunity and phagocytic function.

The history and physical examination may reveal clues which lead to likely diagnoses and further immune evaluation. Despite lack of sensitive and or specific signs and symptoms in respect to PIDs, many red flags including 
specific patterns of infections, autoimmunity, need for intravenous antibiotics, and prolonged oral antibiotics use with little effects have been previously reviewed [143-145]. Additionally, a detailed practice parameter for the evaluation of PID was recently published [146]. A patient history including infections, autoimmunity, malignancy and a review of systems including the presence of constitutional symptoms, allergies, and diarrhea may assist in deciding the likelihood of an immunodeficiency. A family history including consanguinity, early deaths and malignancy will also assist in evaluating for serious causes. The physical exam may note growth parameters, dysmorphism, skin abnormalities, thrush, lymphatic tissue, skin/nail abnormalities and neurological features.

A phenotypic guide to immunological conditions with eosinophilia has been published [6] which contains many of the conditions in this review. Here we present a complimentary approach which focuses on the severity of the conditions followed by some diagnostic clues (Fig. 1). After a detailed history and physical exam, quantitative immunoglobulins could be ordered if a clinical concern of PID exists. Laboratory results of a complete blood count (CBC) and differential will already be available if the reason for referral is eosinophilia. If the patient is lymphopenic or hypogammaglobulinemic then a work up for PID independent of the eosinophilia and comprehensive resources are recommended [146, 147]. A patient with SCID/Omenn syndrome presents a medical emergency so active consideration of these life threatening conditions is warranted in an infant. After considering SCID/Omenn syndrome, other significant or transplantable conditions could be considered such as WAS, IPEX, DOCK8 deficiency, EDA-ID and CD40L/CD40 deficiency and others. Next, consideration of the hyper IgE syndromes is suggested because they are well known to be associated with eosinophilia and some can be severe. Finally, a consideration of the other reported causes may be needed depending on the circumstances and whether an alternate diagnosis has been achieved.

\section{Limitations of this study}

By the nature of a review of published literature, we are limited by what authors have reported. There may be some PIDs with eosinophilia which were not captured due to reporting omission. This limitation is not a weakness because the purpose was to see the basis of the assertion that PID should be considered in a patient with eosinophilia and to catalogue the previously reported conditions. Our strategy did allow the capture of even single case reports and documented many PIDs not typically thought to have been noted with eosinophilia but may have missed some diseases including those which may list the laboratory values in a table in a way not captured by our search, or in non-English language journals.

Determining the true frequency of eosinophilia in individual PID conditions is also subject to reporting omissions and biases. We have provided some information about how commonly eosinophilia has been noted such as from case series of patients, but we cannot provide an exact frequency with this methodology.

The AEC is not described for every PID and therefore the degree and the range of eosinophilia is derived from a low number of cases. The AEC range reported in Table 1 is the cumulative results of the cases which mentioned eosinophil count(s). They are intended to serve as a guide when considering severe eosinophilia. The degree of eosinophilia can be markedly varied in each PID. As summarized in Table 1 and reported in detail in Additional file 1: Table S1, there is a broad variability in the degree of eosinophilia associated with each individual PID and or subtype(s). Given the variability of the degree of eosinophilia this is unlikely to be of major diagnostic assistance, but severe eosinophilia is less common and may have more diagnostic utility.

\section{Conclusions}

There are more PIDs documented with eosinophilia than typically recognized. Eosinophilia has been reported with many primary immunodeficiencies including severe combined, combined, humoral, phagocytic and innate immunodeficiencies. Based on the AEC derived from the literature:

- Severe eosinophilia was seen in OS, WAS, ALPS, STAT3 deficiency, DOCK8 deficiency, IPEX, CD40 deficiency, ZAP70 deficiency, STAT1 deficiency (AD form) and MHC class II deficiency.

- Lesser degree of eosinophilia was described in ADA deficiency, CD3 $\gamma$ deficiency, TCR $\alpha$ deficiency, MALT1 deficiency, Ataxia-telangiectasia, PGM3 deficiency, Tyk2 deficiency, NS, CVID, IgA deficiency, CD40L deficiency, SCN3, cyclic neutropenia, PLS, CGD, EDA-ID, CARD9 deficiency, NOMID/ CINCA, Blau syndrome, and Roifman syndrome.

We agree with previous reviews that PIDs should be considered in patients with eosinophilia, especially children, when typical causes have been ruled out $[2,5-8]$. This list of reported PID conditions with eosinophilia will help with the assessment of such patients. Eosinophilia can be driven by varied processes including imbalances in Th1/Th2, cytokine derangements, infections and medications. 


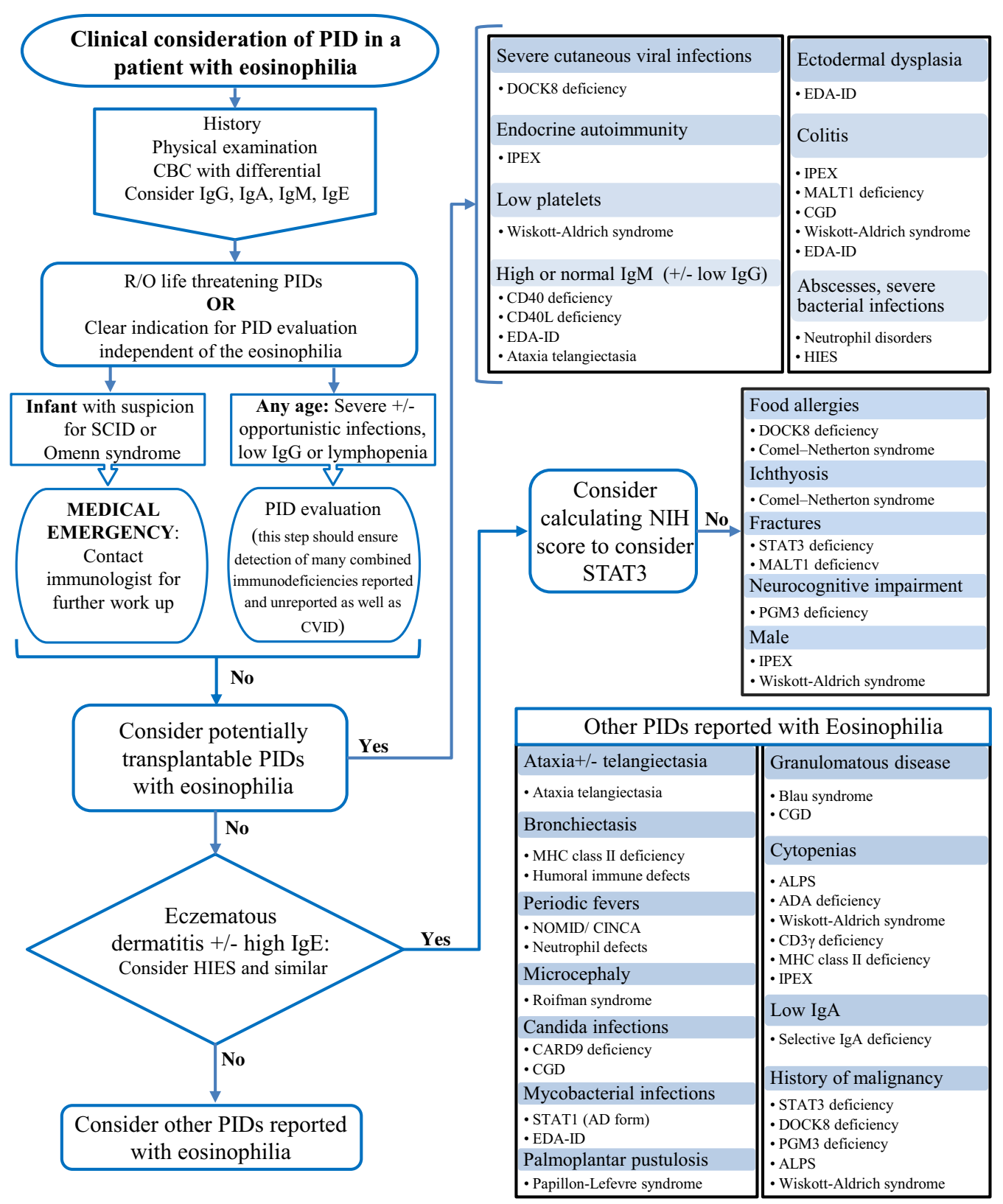

Fig. 1 A Severity-Based Approach to Assessing for PIDs which have been reported with Eosinophilia. The initial approach presented here is based on the history and physical exam and simple laboratory tests. This assessment may reveal independent indications for PID evaluation independent of eosinophilia. In an infant we suggest a low threshold to consider SCID and Omenn syndrome. A consideration of transplantable/severe PIDs is presented next with some phenotypic clues. Then HIES and similarly presenting conditions may be considered in patients with eczematous dermatitis \pm high IgE including performing the NIH score for STAT3 deficiency. Finally, phenotypic clues for other PIDs which have been reported with eosinophilia are listed. This approach does not suggest to evaluate all patients for all disorders but to begin with considering severe causes and then let the phenotype guide investigations for particular conditions. A few conditions, such as WAS and STAT3, appear in multiple locations due to variable presentations

\section{Additional file}

Additional file 1: Table S1. Absolute eosinophil counts (AEC) in Primary Immunodeficiency Diseases (PID): number of patients reported and references cited.

\section{Abbreviations}

PID: primary immunodeficiency disorder; WAS: Wiskott Aldrich syndrome; AEC absolute eosinophil count; IPEX: immunodysregulation polyendocrinopathy enteropathy X-linked; OS: Omenn syndrome; ADA: adenosine deaminase; IUIS: International Union of Immunological Societies; ALPS: autoimmune 
lymphoproliferative syndrome; TCR: T cell receptor; HIES: hyper-lgE syndromes; NS: Comel-Netherton syndrome; CGD: X-linked chronic granulomatous disease; EDA-ID: anhidrotic ectodermal dysplasia-immune deficiency; PLS: Papillon-Lefevre syndrome; CNS: central nervous system; CVID: common variable immunodeficiency disorders; NOMID/CINCA: neonatal onset multisystem inflammatory disease or chronic infantile neurologic cutaneous and articular syndrome; CBC: complete blood count.

\section{Authors' contributions}

BN acquired the data and drafted the manuscript; IU conceived the review, participated in the acquisition of data, and helped to draft and revise the manuscript. Both authors read and approved the final manuscript.

\section{Author details \\ ${ }^{1}$ Department of Paediatrics, The Hospital for Sick Children, University of Toronto, 555 University Avenue, Toronto, ON M5G-1X8, Canada. ${ }^{2}$ Division of Immunology and Allergy, Department of Paediatrics, The Hospital for Sick Children, University of Toronto, 555 University Avenue, Toronto, ON M5G-1X8, Canada.}

\section{Competing interests}

The authors declare that they have no competing interests.

Received: 30 October 2015 Accepted: 21 April 2016 Published online: 24 May 2016

\section{References}

1. Shamri R, Xenakis JJ, Spencer LA. Eosinophils in innate immunity: an evolving story. Cell Tissue Res. 2011;343(1):57-83. doi:10.1007/ s00441-010-1049-6.

2. Curtis C, Ogbogu PU. Evaluation and differential diagnosis of persistent marked eosinophilia. Immunol Allergy Clin North Am. 2015;35(3):387402. doi:10.1016/j.iac.2015.04.001.

3. Rosenberg HF, Dyer KD, Foster PS. Eosinophils: changing perspectives in health and disease. Nat Rev Immunol. 2013;13(1):9-22. doi:10.1038/ nri3341.

4. Roufosse F, Weller PF. Practical approach to the patient with hypereosinophilia. J Allergy Clin Immunol. 2010;126(1):39-44. doi:10.1016/j. jaci.2010.04.011.

5. Mejia R, Nutman TB. Evaluation and differential diagnosis of marked, persistent eosinophilia. Semin Hematol. 2012;49(2):149-59. doi:10.1053/j.seminhematol.2012.01.006.

6. Williams KW, Milner JD, Freeman AF. Eosinophilia associated with disorders of immune deficiency or immune dysregulation. Immuno Allergy Clinics N Am. 2015;35(3):523-44. doi:10.1016/j.iac.2015.05.004.

7. Nutman TB. Evaluation and differential diagnosis of marked, persistent eosinophilia. Immuno Allergy Clinics N Am. 2007;27(3):529-49. doi:10.1016/j.iac.2007.07.008.

8. Montgomery ND, Dunphy CH, Mooberry M, Laramore A, Foster MC, Park SI, et al. Diagnostic complexities of eosinophilia. Arch Pathol Lab Med. 2013;137(2):259-69. doi:10.5858/arpa.2011-0597-RA.

9. Al-Herz W, Bousfiha A, Casanova JL, Chatila T, Conley ME, CunninghamRundles $C$, et al. Primary immunodeficiency diseases: an update on the classification from the international union of immunological societies expert committee for primary immunodeficiency. Front Immunol. 2014;5:162. doi:10.3389/fimmu.2014.00162.

10. Fuchs S, Rensing-Ehl A, Pannicke U, Lorenz MR, Fisch P, Jeelall Y, et al. Omenn syndrome associated with a functional reversion due to a somatic second-site mutation in CARD11 deficiency. Blood. 2015. doi:10.1182/blood-2015-03-631374.

11. Villa A, Notarangelo LD, Roifman CM. Omenn syndrome: inflammation in leaky severe combined immunodeficiency. J Allergy Clin Immunol. 2008;122(6):1082-6. doi:10.1016/j.jaci.2008.09.037.

12. Zhang Y, Yu X, Ichikawa M, Lyons JJ, Datta S, Lamborn IT, et al. Autosomal recessive phosphoglucomutase 3 (PGM3) mutations link glycosylation defects to atopy, immune deficiency, autoimmunity, and neurocognitive impairment. J Allergy Clin Immunol. 2014;133(5):14009. doi:10.1016/j.jaci.2014.02.013.
13. Roifman CM. Antibody deficiency, growth retardation, spondyloepiphyseal dysplasia and retinal dystrophy: a novel syndrome. Clin Genet. 1999;55(2):103-9.

14. Merico D, Roifman M, Braunschweig U. Compound heterozygous mutations in the noncoding RNU4ATAC cause Roifman Syndrome by disrupting minor intron splicing. 2015; 6: 8718. doi:10.1038/ncomms9718.

15. McKinnon ML RJ FS, Hirschfeld A, Del Bel K, Thomas L, Marr N, Martin S, Senger C, Tsang A, Prendiville J, Junker A, Seear M, Schultz K, Sly L, Holt R, Patel M, Friedman JM, Turvey S. Identification of Human MALT1 Deficiency and Role of the NF-kappa B pathway in a Novel Autosomal Recessive Immune Deficiency and Dysregulation Disorder. 2013. http://www.ashg.org/2013meeting/abstracts/fulltext/f130123561.htm. Accessed 22 October 2015.

16. Balasubramaniam S, Duley JA, Christodoulou J. Inborn errors of purine metabolism: clinical update and therapies. J Inherit Metab Dis. 2014;37(5):669-86. doi:10.1007/s10545-014-9731-6.

17. Roifman CM, Zhang J, Atkinson A, Grunebaum E, Mandel K. Adenosine deaminase deficiency can present with features of Omenn syndrome. J Allergy Clin Immunol. 2008;121(4):1056-8. doi:10.1016/j. jaci.2007.12.1148.

18. Artac H, Gokturk B, Bozdemir SE, Toy H, van der Burg M, Santisteban I, et al. Late-onset adenosine deaminase deficiency presenting with Heck's disease. Eur J Pediatr. 2010;169(8):1033-6. doi:10.1007/ s00431-009-1131-9.

19. Fischer A. Severe combined immunodeficiencies (SCID). Clin Exp Immunol. 2000;122(2):143-9.

20. Hartel C, Strunk T, Bucsky P, Schultz C. Failure to thrive in a 14-month-old boy with lymphopenia and eosinophilia. Klin Padiatr. 2004;216(1):24-5. doi:10.1055/s-2004-817993.

21. Levy Y, Hershfield MS, Fernandez-Mejia C, Polmar SH, Scudiery D, Berger $\mathrm{M}$, et al. Adenosine deaminase deficiency with late onset of recurrent infections: response to treatment with polyethylene glycol-modified adenosine deaminase. J Pediatr. 1988;113(2):312-7.

22. Santisteban I, Arredondo-Vega FX, Kelly S, Mary A, Fischer A, Hummell DS, et al. Novel splicing, missense, and deletion mutations in seven adenosine deaminase-deficient patients with late/delayed onset of combined immunodeficiency disease. Contribution of genotype to phenotype. J Clin Investig. 1993;92(5):2291-302. doi:10.1172/JCI116833.

23. Gokturk B, Keles S, Kirac M, Artac H, Tokgoz H, Guner SN, et al. CD3G gene defects in familial autoimmune thyroiditis. Scand J Immunol. 2014;80(5):354-61. doi:10.1111/sji.12200.

24. Tokgoz H, Caliskan U, Keles S, Reisli I, Guiu IS, Morgan NV. Variable presentation of primary immune deficiency: two cases with CD3 gamma deficiency presenting with only autoimmunity. Pediatr Allergy Immunol. 2013;24(3):257-62. doi:10.1111/pai.12063.

25. Arnaiz-Villena A, Timon M, Corell A, Perez-Aciego P, Martin-Villa JM, Regueiro JR. Brief report: primary immunodeficiency caused by mutations in the gene encoding the CD3-gamma subunit of the T-lymphocyte receptor. New Engl J Med. 1992;327(8):529-33. doi:10.1056/ nejm199208203270805.

26. Negishi I, Motoyama N, Nakayama K, Nakayama K, Senju S, Hatakeyama $\mathrm{S}$, et al. Essential role for ZAP-70 in both positive and negative selection of thymocytes. Nature. 1995;376(6539):435-8. doi:10.1038/376435a0.

27. Starr TK, Jameson SC, Hogquist KA. Positive and negative selection of T cells. Annu Rev Immunol. 2003;21:139-76. doi:10.1146/annurev. immunol.21.120601.141107.

28. Turul T, Tezcan I, Artac H, de Bruin-Versteeg S, Barendregt BH, Reisli I, et al. Clinical heterogeneity can hamper the diagnosis of patients with ZAP70 deficiency. Eur J Pediatr. 2009;168(1):87-93. doi:10.1007/ s00431-008-0718-x.

29. Katamura K, Tai G, Tachibana T, Yamabe H, Ohmori K, Mayumi M, et al. Existence of activated and memory CD4 $+T$ cells in peripheral blood and their skin infiltration in CD8 deficiency. Clin Exp Immunol. 1999;115(1):124-30.

30. Hernandez-Trujillo V. New genetic discoveries and primary immune deficiencies. Clin Rev Allergy Immunol. 2014;46(2):145-53. doi:10.1007/ s12016-013-8380-0.

31. Ouederni M, Vincent QB, Frange P, Touzot F, Scerra S, Bejaoui M, et al. Major histocompatibility complex class II expression deficiency caused by a RFXANK founder mutation: a survey of 35 patients. Blood. 2011;118(19):5108-18. doi:10.1182/blood-2011-05-352716. 
32. Nekrep N, Fontes JD, Geyer M, Peterlin BM. When the lymphocyte loses its clothes. Immunity. 2003;18(4):453-7.

33. Lev A, Simon AJ, Trakhtenbrot L, Goldstein I, Nagar M, Stepensky P et al. Characterizing T cells in SCID patients presenting with reactive or residual T lymphocytes. Clin Developmental Immunol. 2012.

34. Winter M, Kashani E, Chennupati V, Fohse L, Prinz I. Visualization and quantification of monoallelic TCRalpha gene rearrangement in alphabeta T cells. Immunol Cell Biol. 2014;92(5):409-16. doi:10.1038/ icb.2013.105.

35. Borowski C, Li X, Aifantis I, Gounari F, von Boehmer H. Pre-TCRa and TCRa Are Not Interchangeable Partners of TCR 3 during T Lymphocyte Development. J Exp Med. 2004;199(5):607-15. doi:10.1084/ jem.20031973.

36. Fehling HJ, Krotkova A, Saint-Ruf C, von Boehmer H. Crucial role of the pre-T-cell receptor alpha gene in development of alpha beta but not gamma delta T cells. Nature. 1995;375(6534):795-8. doi:10.1038/375795a0.

37. Morgan NV, Goddard S, Cardno TS, McDonald D, Rahman F, Barge D, et al. Mutation in the TCRalpha subunit constant gene (TRAC) leads to a human immunodeficiency disorder characterized by a lack of TCRalphabeta + T cells. J Clin Investig. 2011;121(2):695-702. doi:10.1172/ jci41931.

38. McKinnon ML, Rozmus J, Fung SY, Hirschfeld AF, Del Bel KL, Thomas $L$, et al. Combined immunodeficiency associated with homozygous MALT1 mutations. J Allergy Clinical Immunol. 2014;133(5):1458-62. doi:10.1016/.jaci.2013.10.045.

39. Turvey SE, Durandy A, Fischer A, Fung SY, Geha RS, Gewies A, et al. The CARD11-BCL10-MALT1 (CBM) signalosome complex: stepping into the limelight of human primary immunodeficiency. J Allergy Clin Immunol. 2014;134(2):276-84. doi:10.1016/j.jaci.2014.06.015.

40. Omenn GS. Familial reticuloendotheliosis with eosinophilia. New Engl J Med. 1965;273:427-32. doi:10.1056/nejm196508192730806.

41. Felgentreff K, Perez-Becker R, Speckmann C, Schwarz K, Kalwak K, Markelj $G$, et al. Clinical and immunological manifestations of patients with atypical severe combined immunodeficiency. Clin Immunol (Orlando, Fla). 2011;141(1):73-82. doi:10.1016/j.clim.2011.05.007.

42. Gennery AR, Hodges E, Williams AP, Harris S, Villa A, Angus B, et al. Omenn's syndrome occurring in patients without mutations in recombination activating genes. Clin Immunol (Orlando, Fla). 2005;116(3):246-56. doi:10.1016/j.clim.2005.04.014.

43. Roifman CM, Gu Y, Cohen A. Mutations in the RNA component of RNase mitochondrial RNA processing might cause Omenn syndrome. J Allergy Clin Immunol. 2006;117(4):897-903. doi:10.1016/j.jaci.2006.01.003.

44. Kavadas FD, Giliani S, Gu Y, Mazzolari E, Bates A, Pegoiani E, et al. Variability of clinical and laboratory features among patients with ribonuclease mitochondrial RNA processing endoribonuclease gene mutations. J Allergy Clin Immunol. 2008;122(6):1178-84. doi:10.1016/j. jaci.2008.07.036

45. Henderson LA, Frugoni F, Hopkins G, Al-Herz W, Weinacht K, Comeau $\mathrm{AM}$, et al. First reported case of Omenn syndrome in a patient with reticular dysgenesis. J Allergy Clin Immunol. 2013;131(4):1227-30.

46. Markert ML, Alexieff MJ, Li J, Sarzotti M, Ozaki DA, Devlin BH, et al. Complete DiGeorge syndrome: development of rash, lymphadenopathy, and oligoclonal T cells in 5 cases. J Allergy Clin Immunol. 2004;113(4):734-41. doi:10.1016/j.jaci.2004.01.766.

47. Vu QV, Wada T, Toma T, Tajima H, Maeda M, Tanaka R, et al. Clinical and immunophenotypic features of atypical complete DiGeorge syndrome. Pediatr Int. 2013;55(1):2-6. doi:10.1111/j.1442-200X.2012.03722.x.

48. Moulding DA, Record J, Malinova D, Thrasher AJ. Actin cytoskeletal defects in immunodeficiency. Immunol Rev. 2013;256(1):282-99. doi:10.1111/imr.12114.

49. Orange JS, Stone KD, Turvey SE, Krzewski K. The Wiskott-Aldrich syndrome. Cell Mol Life Sci. 2004;61 (18):2361-85. doi:10.1007/ s00018-004-4086-z.

50. Sullivan KE, Mullen CA, Blaese RM, Winkelstein JA. A multiinstitutional survey of the Wiskott-Aldrich syndrome. J Pediatr. 1994;125(6 Pt 1):876-85.

51. Stiehm ER, McIntosh RM. Wiskott-Aldrich syndrome: review and report of a large family. Clin Exp Immunol. 1967;2(2):179-89.

52. Lavin MF, Shiloh Y. The genetic defect in ataxia-telangiectasia. Annu Rev Immunol. 1997;15:177-202. doi:10.1146/annurev.immunol.15.1.177.
53. Centerwall WR, Miller MM. Ataxia, telangiectasia, and sinopulmonary infections: a syndrome of slowly progressive deterioration in childhood. AMA J Dis Child. 1958;95(4):385-96. doi:10.1001/ archpedi.1958.02060050387007.

54. Kanaganayagam A. Ataxia telangiectasia-a case report. Med J Malays. 1980;35(2):139-43.

55. Minegishi Y, Karasuyama H. Defects in Jak-STAT-mediated cytokine signals cause hyper-IgE syndrome: lessons from a primary immunodeficiency. Int Immunol. 2009;21(2):105-12. doi:10.1093/intimm/dxn134.

56. Heimall J, Freeman A, Holland SM. Pathogenesis of hyper lgE syndrome. Clin Rev Allergy Immunol. 2010;38(1):32-8. doi:10.1007/ s12016-009-8134-1.

57. Avery DT, Deenick EK, Ma CS, Suryani S, Simpson N, Chew GY, et al. B cell-intrinsic signaling through IL-21 receptor and STAT3 is required for establishing long-lived antibody responses in humans. J Exp Med. 2010;207(1):155-71. doi:10.1084/jem.20091706.

58. Yong PF, Freeman AF, Engelhardt KR, Holland S, Puck JM, Grimbacher B. An update on the hyper-IgE syndromes. Arthr Res Ther. 2012;14(6):228. doi:10.1186/ar4069.

59. Chandesris MO, Melki I, Natividad A, Puel A, Fieschi C, Yun L, et al. Autosomal dominant STAT3 deficiency and hyper-IgE syndrome: molecular, cellular, and clinical features from a French national survey. Medicine. 2012;91(4):e1-19. doi:10.1097/MD.0b013e31825f95b9.

60. Walker S, Wang C, Walradt T, Hong BS, Tanner JR, Levinsohn JL, et al. Identification of a gain-of-function STAT3 mutation (p. Y640F) in lymphocytic variant hypereosinophilic syndrome. Blood. 2016;127(7):94851. doi:10.1182/blood-2015-06-654277.

61. Engelhardt KR, McGhee S, Winkler S, Sassi A, Woellner C, Lopez-Herrera $\mathrm{G}$, et al. Large deletions and point mutations involving the dedicator of cytokinesis 8 (DOCK8) in the autosomal-recessive form of hyper-lgE syndrome. J Allergy Clin Immunol. 2009;124(6):1289-302. doi:10.1016/j. jaci.2009.10.038.

62. Zhang Q, Davis JC, Lamborn IT, Freeman AF, Jing H, Favreau AJ, et al. Combined immunodeficiency associated with DOCK8 mutations. New Eng J Med. 2009:361(21):2046-55. doi:10.1056/NEJMoa0905506.

63. Aydin SE, Kilic SS, Aytekin C, Kumar A, Porras O, Kainulainen L, et al. DOCK8 deficiency: clinical and immunological phenotype and treatment options-a review of 136 patients. J Clin Immunol. 2015;35(2):189-98. doi:10.1007/s10875-014-0126-0.

64. Su HC. Dedicator of cytokinesis 8 (DOCK8) deficiency. Curr Opin Allergy Clin Immunol. 2010;10(6):515-20. doi:10.1097/ACl.0b013e32833fd718.

65. Renner ED, Puck JM, Holland SM, Schmitt M, Weiss M, Frosch M, et al. Autosomal recessive hyperimmunoglobulin E syndrome: a distinct disease entity. J Pediatr. 2004;144(1):93-9. doi:10.1016/ s0022-3476(03)00449-9.

66. Chu EY, Freeman AF, Jing H, Cowen EW, Davis J, Su HC, et al. Cutaneous manifestations of DOCK8 deficiency syndrome. Arch Dermatol. 2012;148(1):79-84. doi:10.1001/archdermatol.2011.262.

67. Mogensen TH. Primary immunodeficiencies with elevated IgE. Int Rev Immunol. 2015;9:1-18. doi:10.3109/08830185.2015.1027820.

68. Kreins AY, Ciancanelli MJ, Okada S, Kong XF, Ramirez-Alejo N, Kilic SS, et al. Human TYK2 deficiency: mycobacterial and viral infections without hyper-IgE syndrome. J Exp Med. 2015;212(10):1641-62. doi:10.1084/ jem.20140280.

69. Minegishi Y, Saito M, Morio T, Watanabe K, Agematsu K, Tsuchiya S, et al. Human tyrosine kinase 2 deficiency reveals its requisite roles in multiple cytokine signals involved in innate and acquired immunity. Immunity. 2006;25(5):745-55. doi:10.1016/j.immuni.2006.09.009.

70. Furio L, Hovnanian A. Netherton syndrome: defective kallikrein inhibition in the skin leads to skin inflammation and allergy. Biol Chem. 2014;395(9):945-58. doi:10.1515/hsz-2014-0137.

71. Hovnanian A. Netherton syndrome: skin inflammation and allergy by loss of protease inhibition. Cell Tissue Res. 2013;351(2):289-300. doi:10.1007/s00441-013-1558-1.

72. Boussofara L, Ghannouchi N, Ghariani N, Denguezli M, Belajouza C, Nouira R. Netherton's syndrome: the importance of eyebrow hair. Dermatol Online J. 2007;13(3):21.

73. Renner ED, Hartl D, Rylaarsdam S, Young ML, Monaco-Shawver L, Kleiner $\mathrm{G}$, et al. Comel-Netherton syndrome defined as primary immunodeficiency. J Allergy Clin Immunol. 2009;124(3):536-43. doi:10.1016/j. jaci.2009.06.009. 
74. Altman J, Stroud J. Neterton's syndrome and ichthyosis linearis circumflexa. Arch Dermatol. 1969;100(5):550-8.

75. Smith DL, Smith JG, Wong SW, deShazo RD. Netherton's syndrome: a syndrome of elevated IgE and characteristic skin and hair findings. J Allergy Clin Immunol. 1995;95(1 Pt 1):116-23.

76. Yong PF, Tarzi M, Chua I, Grimbacher B, Chee R. Common variable immunodeficiency: an update on etiology and management. Immunol Allergy Clin N Am. 2008;28(2):367-86. doi:10.1016/j.iac.2008.01.001.

77. Abbott JK, Gelfand EW. Common variable immunodeficiency. Immunol Allergy Clin. 2015;35(4):637-58. doi:10.1016/j.jac.2015.07.009.

78. Adams ST, Schmidt KM, Cost KM, Marshall GS. Common variable immunodeficiency presenting with persistent parvovirus B19 infection. Pediatrics. 2012;130(6):e1711-5. doi:10.1542/peds.2011-2556.

79. Kubota M, Nakamura K, Watanabe K, Kimata H, Mikawa H. A case of common variable immunodeficiency associated with cyclic thrombocytopenia. Acta Paediatr Japonica. 1994;36(6):690-2.

80. Skeik N, Rumery KK, Udayakumar PD, Crandall BM, Warrington KJ, Sullivan TM. Concurrent Takayasu arteritis with common variable immunodeficiency and moyamoya disease. Ann Vascular Surg. 2013;27(2):240. doi:10.1016/j.avsg.2012.09.003.

81. Davies EG, Thrasher AJ. Update on the hyper immunoglobulin M syndromes. Br J Haematol. 2010;149(2):167-80. doi:10.1111/j.1365-2141.2010.08077.x.

82. Merchant RH, Ahmed J, Ahmed N, Picard C. Type capital I, Ukrainian hyper IgM syndrome with novel mutation from India. Indian J Pediatr. 2014:81(6):620-2. doi:10.1007/s12098-013-1029-4.

83. Guo LI, Chen BO, Xu B, Lu M, Ning B, Chen Z. X-linked hyper-lgM syndrome with eosinophilia in a male child: a case report. Exp Ther Med. 2015;9(4):1328-30. doi:10.3892/etm.2015.2261.

84. Jo EK, Kim HS, Lee MY, Iseki M, Lee JH, Song CH, et al. X-linked hyperIgM syndrome associated with Cryptosporidium parvum and Cryptococcus neoformans infections: the first case with molecular diagnosis in Korea. J Korean Med Sci. 2002;17(1):116-20

85. Ferrari S, Giliani S, Insalaco A, Al-Ghonaium A, Soresina AR, Loubser $M$, et al. Mutations of CD40 gene cause an autosomal recessive form of immunodeficiency with hyper IgM. Proc Natl Acad Sci USA. 2001;98(22):12614-9. doi:10.1073/pnas.221456898.

86. Kutukculer N, Moratto D, Aydinok Y, Lougaris V, Aksoylar S, Plebani A, et al. Disseminated cryptosporidium infection in an infant with hyperIgM syndrome caused by CD40 deficiency. J Pediatr. 2003;142(2):194-6. doi:10.1067/mpd.2003.41.

87. Lougaris V, Badolato R, Ferrari S, Plebani A. Hyper immunoglobulin M syndrome due to CD40 deficiency: clinical, molecular, and immunological features. Immunol Rev. 2005;203:48-66. doi:10.1111/j.0105-2896.2005.00229.x.

88. Yel L. Selective IgA deficiency. J Clin Immunol. 2010;30(1):10-6.

89. Cunningham-Rundles C. Physiology of IgA and IgA deficiency. J Clin Immunol. 2001;21(5):303-9.

90. Fauci AS, Harley JB, Roberts WC, Ferrans VJ, Gralnick HR, Bjornson BH. The idiopathic hypereosinophilic syndrome. Clinical, pathophysiologic, and therapeutic considerations. Ann Intern Med. 1982;97(1):78-92.

91. Messa E, Cilloni D, Saglio G. A young man with persistent eosinophilia. Intern Emerg Med. 2007;2(2):107-12.

92. XavierdaSilva MM, MoreiraFilho CA, Suzuki E, Patricio F, Coutinho A, Carneiro-Sampaio M. Fetalonset IPEX: Report of two families and review of literature. Clin Immunol (Orlando, Fla). 2015;156(2):131-40 doi:10.1016/j.clim.2014.12.007.

93. Verbsky JW, Chatila TA. Immune dysregulation, polyendocrinopathy, enteropathy, X-linked (IPEX) and IPEX-related disorders: an evolving web of heritable autoimmune diseases. Curr Opin Pediatr. 2013;25(6):708-14. doi:10.1097/mop.0000000000000029.

94. Torgerson TR, Ochs HD. Immune dysregulation, polyendocrinopathy, enteropathy, X-linked: forkhead box protein 3 mutations and lack of regulatory T cells. J Allergy Clin Immunol. 2007;120(4):744-50. doi:10.1016/j.jaci.2007.08.044.

95. Ozcan E, Notarangelo LD, Geha RS. Primary immune deficiencies with aberrant IgE production. J Allergy Clin Immunol. 2008;122(6):1054-62. doi:10.1016/j.jaci.2008.10.023.

96. Gambineri E, Perroni L, Passerini L, Bianchi L, Doglioni C, Meschi F, et al. Clinical and molecular profile of a new series of patients with immune dysregulation, polyendocrinopathy, enteropathy, X-linked syndrome: inconsistent correlation between forkhead box protein 3 expression and disease severity. J Allergy Clin Immunol. 2008;122(6):1105-12. doi:10.1016/j.jaci.2008.09.027.

97. Savova R, Arshinkova M, Houghton J, Konstantinova M, Gaydarova M, Georgieva E, et al. Clinical case of immune dysregulation, polyendocrinopaty, enteropathy, X-linked (IPEX) syndrome with severe immune deficiency and late onset of endocrinopathy and enteropathy. Case Rep Med. 2014;2014:564926. doi:10.1155/2014/564926.

98. Wildin RS, Smyk-Pearson S, Filipovich AH. Clinical and molecular features of the immunodysregulation, polyendocrinopathy, enteropathy, $X$ linked (IPEX) syndrome. J Med Genet. 2002;39(8):537-45.

99. Madkaikar M, Mhatre S, Gupta M, Ghosh K. Advances in autoimmune lymphoproliferative syndromes. Eur J Haematol. 2011;87(1):1-9. doi:10.1111/j.1600-0609.2011.01617.x.

100. Bleesing JJ. Autoimmune lymphoproliferative syndrome (ALPS). Curr Pharm Des. 2003;9(3):265-78.

101. Sneller MC, Dale JK, Straus SE. Autoimmune lymphoproliferative syndrome. Curr Opin Rheumatol. 2003;15(4):417-21.

102. Sneller MC, Straus SE, Jaffe ES, Jaffe JS, Fleisher TA, Stetler-Stevenson M, et al. A novel lymphoproliferative/autoimmune syndrome resembling murine Ipr/gld disease. J Clin Investig. 1992;90(2):334-41. doi:10.1172/ jci115867.

103. Bleesing JJH, Brown MR, Novicio C, Guarraia D, Dale JK, Straus SE, et al. A composite picture of TcRa/ $\beta+C D 4-C D 8-T$ Cells ( $\alpha / \beta$-DNTCs) in humans with autoimmune lymphoproliferative syndrome. Clin Immunol. 2002;104(1):21-30. doi:10.1006/clim.2002.5225.

104. Kim YJ, Dale JK, Noel P, Brown MR, Nutman TB, Straus SE, et al. Eosinophilia is associated with a higher mortality rate among patients with autoimmune lymphoproliferative syndrome. Am J Hematol. 2007;82(7):615-24. doi:10.1002/ajh.20851.

105. Del-Rey MJ, Manzanares J, Bosque A, Aguiló Jl, Gómez-Rial J, Roldan $E$, et al. Autoimmune lymphoproliferative syndrome (ALPS) in a patient with a new germline Fas gene mutation. Immunobiology 2007;212(2):73-83. doi:10.1016/j.imbio.2006.12.003.

106. Ancliff PJ. Congenital neutropenia. Blood Rev. 2003;17(4):209-16.

107. Welte K, Zeidler C, Dale DC. Severe congenital neutropenia. Semin Hematol. 2006;43(3):189-95. doi:10.1053/j. seminhematol.2006.04.004.

108. Carlsson G, Andersson M, Putsep K, Garwicz D, Nordenskjold M, Henter $\mathrm{Jl}$, et al. Kostmann syndrome or infantile genetic agranulocytosis, part one: celebrating 50 years of clinical and basic research on severe congenital neutropenia. Acta Paediatr (Oslo, Norway). 2006;95(12):1526-32. doi:10.1080/08035250601087607.

109. Donadieu J, Fenneteau O, Beaupain B, Mahlaoui N, Chantelot CB. Congenital neutropenia: diagnosis, molecular bases and patient management. Orphanet J Rare Dis. 2011;6:26. doi:10.1186/1750-1172-6-26.

110. Lange RD, Jones JB. Cyclic neutropenia review of clinical manifestations and management. J Pediatr Hematol Oncol. 1981;3(4):363-8.

111. Pratchyapruit WO, Kullavanijaya P. Papillon-Lefevre syndrome: a case report. J Dermatol. 2002;29(6):329-35.

112. Toomes C, James J, Wood AJ, Wu CL, McCormick D, Lench N, et al. Lossof-function mutations in the cathepsin $C$ gene result in periodontal disease and palmoplantar keratosis. Nat Genet. 1999;23(4):421-4. doi:10.1038/70525.

113. Naik DN, Velou A, Alavandar G, Radharkrishna BK. Papillon-Lefevre syndrome. Oral Surg Oral Med Oral Pathol. 1968;25(1):19-23.

114. Goldblatt D, Thrasher AJ. Chronic granulomatous disease. Clin Exp Immunol. 2000;122(1):1-9.

115. Jaggi P, Freeman AF, Katz BZ. Chronic granulomatous disease presenting with eosinophilic inflammation. Pediatr Infect Dis J. 2005;24(11):1020-1.

116. Barese CN, Podesta M, Litvak E, Villa M, Rivas EM. Recurrent eosinophilic cystitis in a child with chronic granulomatous disease. J Pediatr Hematol Oncol. 2004;26(3):209-12.

117. Kristensen IA, Veirum JE, Moller BK, Christiansen M. Novel STAT1 alleles in a patient with impaired resistance to mycobacteria. J Clin Immunol. 2011;31(2):265-71. doi:10.1007/s10875-010-9480-8.

118. Hirata O, Okada S, Tsumura M, Kagawa R, Miki M, Kawaguchi H, et al. Heterozygosity for the Y701C STAT1 mutation in a multiplex kindred with multifocal osteomyelitis. Haematologica. 2013;98(10):1641-9. doi:10.3324/haematol.2013.083741. 
119. Vairo D, Tassone L, Tabellini G, Tamassia N, Gasperini S, Bazzoni F, et al. Severe impairment of IFN-gamma and IFN-alpha responses in cells of a patient with a novel STAT1 splicing mutation. Blood. 2011;118(7):180617. doi:10.1182/blood-2011-01-330571.

120. Smahi A, Courtois G, Rabia SH, Doffinger R, Bodemer C, Munnich A, et al. The NF-kappaB signalling pathway in human diseases: from incontinentia pigmenti to ectodermal dysplasias and immune-deficiency syndromes. Hum Mol Genet. 2002;11(20):2371-5.

121. Braue J, Murugesan V, Holland S, Patel N, Naik E, Leiding J, et al. NF-kappaB essential modulator deficiency leading to disseminated cutaneous atypical mycobacteria. Mediterr J Hematol Infect Dis. 2015;7(1):e2015010. doi:10.4084/mjhid.2015.010.

122. Orange JS, Jain A, Ballas ZK, Schneider LC, Geha RS, Bonilla FA. The presentation and natural history of immunodeficiency caused by nuclear factor kB essential modulator mutation. J Allergy Clin Immunol. 2014;113(4):725-33. doi:10.1016/j.jaci.2004.01.762.

123. Martinez-Pomar N, Munoz-Saa I, Heine-Suner D, Martin A, Smahi A, Matamoros N. A new mutation in exon 7 of NEMO gene: late skewed $X$-chromosome inactivation in an incontinentia pigment female patient with immuno deficiency. Hum Genet. 2005;1 18(3-4):458-65. doi:10.1007/s00439-005-0068-y.

124. Mancini AJ, Lawley LP, Uzel G. X-linked ectodermal dysplasia with immunodeficiency caused by NEMO mutation: early recognition and diagnosis. Arch Dermatol. 2008;144(3):342-6. doi:10.1001/ archderm.144.3.342.

125. Orange JS, Jain A, Ballas ZK, Schneider LC, Geha RS, Bonilla FA. The presentation and natural history of immunodeficiency caused by nuclear factor kappaB essential modulator mutation. J Allergy Clin Immunol. 2004;113(4):725-33. doi:10.1016/j.jaci.2004.01.762.

126. Drewniak A, Gazendam RP, Tool AT, van Houdt M, Jansen MH, van Hamme $J$, et al. Invasive fungal infection and impaired neutrophil killing in human CARD9 deficiency. Blood. 2013;121(13):2385-92. doi:10.1182/blood-2012-08-450551.

127. Lanternier F, Pathan S, Vincent QB, Liu L, Cypowyj S, Prando C, et al. Deep dermatophytosis and inherited CARD9 deficiency. N Engl J Med. 2013;369(18):1704-14. doi:10.1056/NEJMoa1208487.

128. Grumach AS, de Queiroz-Telles F, Migaud M, Lanternier F, Filho NR, Palma SM, et al. A homozygous CARD9 mutation in a Brazilian patient with deep dermatophytosis. J Clin Immunol. 2015;35(5):486-90. doi:10.1007/s10875-015-0170-4.

129. Herbst M, Gazendam R, Reimnitz D, Sawalle-Belohradsky J, Groll A, Schlegel PG, et al. Chronic candida albicans meningitis in a 4-year-old girl with a homozygous mutation in the CARD9 gene (Q295X). Pediatr Infect Dis J. 2015:34(9):999-1002. doi:10.1097/inf.00000000000000736.

130. Aksentijevich I, Nowak M, Mallah M, Chae JJ, Watford WT, Hofmann SR, et al. De novo CIAS1 mutations, cytokine activation, and evidence for genetic heterogeneity in patients with neonatal-onset multisystem inflammatory disease (NOMID): a new member of the expanding family of pyrin-associated autoinflammatory diseases. Arthritis Rheum. 2002;46(12):3340-8. doi:10.1002/art.10688.

131. Davila-Seijo P, Hernandez-Martin A, Torrelo A. Autoinflammatory syndromes for the dermatologist. Clin Dermatol. 2014;32(4):488-501. doi:10.1016/..clindermatol.2014.02.004.

132. Feldmann J, Prieur AM, Quartier P, Berquin P, Certain S, Cortis E, et al. Chronic infantile neurological cutaneous and articular syndrome is caused by mutations in CIAS1, a gene highly expressed in polymorphonuclear cells and chondrocytes. Am J Hum Genet. 2002;11(1):198-203.

133. Sfriso P, Caso F, Tognon S, Galozzi P, Gava A, Punzi L. Blau syndrome, clinical and genetic aspects. Autoimmun Rev. 2012;12(1):44-51. doi:10.1016/j.autrev.2012.07.028.

134. Blau EB. Familial granulomatous arthritis, iritis, and rash. J Pediatr. 1985;107(5):689-93

135. Pattishall EN, Strope GL, Spinola SM, Denny FW. Childhood sarcoidosis. J Pediatr. 1986;108(2):169-77.

136. Rodriguez GE, Shin BC, Abernathy RS, Kendig EL Jr. Serum angiotensinconverting enzyme activity in normal children and in those with sarcoidosis. J Pediatr. 1981;99(1):68-72.

137. Shetty AK, Gedalia A. Childhood sarcoidosis: a rare but fascinating disorder. Pediatr Rheumatol Online J. 2008;6:16. doi:10.1186/1546-0096-6-16.

138. Glass DA 2nd, Maender J, Metry D. Two pediatric cases of Blau syndrome. Dermatol Online J. 2009;15(12):5.
139. Caso F, Galozzi P, Costa L, Sfriso P, Cantarini L, Punzi L. Autoinflammatory granulomatous diseases: from Blau syndrome and early-onset sarcoidosis to NOD2-mediated disease and Crohn's disease. RMD Open. 2015;1 (1):e000097. doi:10.1136/rmdopen-2015-000097.

140. Yang L, Fliegauf M, Grimbacher B. Hyper-IgE syndromes: reviewing PGM3 deficiency. Curr Opin Pediatr. 2014;26(6):697-703. doi:10.1097/ mop.0000000000000158.

141. Stray-Pedersen A, Backe Paul H, Sorte Hanne S, Mørkrid L, Chokshi Niti Y, Erichsen Hans C, et al. PGM3 mutations cause a congenital disorder of glycosylation with severe immunodeficiency and skeletal dysplasia. Am J Hum Genet. 2014;95(1):96-107. doi:10.1016/j. ajhg.2014.05.007.

142. Sassi A, Lazaroski S, Wu G, Haslam SM, Fliegauf M, Mellouli F, et al. Hypomorphic homozygous mutations in phosphoglucomutase 3 (PGM3) impair immunity and increase serum IgE levels. J Allergy Clin Immunol. 2014;133(5):1410-9. doi:10.1016/j.jaci.2014.02.025.

143. Costa-Carvalho BT, Grumach AS, Franco JL, Espinosa-Rosales FJ, Leiva $L E$, King $A$, et al. Attending to warning signs of primary immunodeficiency diseases across the range of clinical practice. J Clin Immunol. 2014;34(1):10-22. doi:10.1007/s10875-013-9954-6.

144. Subbarayan A, Colarusso G, Hughes SM, Gennery AR, Slatter M, Cant AJ, et al. Clinical features that identify children with primary immunodeficiency diseases. Pediatrics. 2011;127(5):810-6. doi:10.1542/ peds.2010-3680.

145. Arkwright PD, Gennery AR. Ten warning signs of primary immunodeficiency: a new paradigm is needed for the 21 st century. Ann NY Acad Sci. 2011;1238:7-14. doi:10.1111/j.1749-6632.2011.06206.x.

146. Bonilla FA, Khan DA, Ballas ZK, Chinen J, Frank MM, Hsu JT, et al. Practice parameter for the diagnosis and management of primary immunodeficiency. J Allergy Clin Immunol. 2015;136(5):1186-205. doi:10.1016/j. jaci.2015.04.049.

147. Bousfiha AA, Jeddane L, Ailal F, Al Herz W, Conley ME, CunninghamRundles C, et al. A phenotypic approach for IUIS PID classification and diagnosis: guidelines for clinicians at the bedside. J Clin Immunol. 2013;33(6):1078-87. doi:10.1007/s10875-013-9901-6.

148. Zhang LY, Tian W, Shu L, Jiang LP, Zhan YZ, Liu W, et al. Clinical features, STAT3 gene mutations and Th17 cell analysis in nine children with hyper-IgE syndrome in mainland China. Scand J Immunol. 2013;78(3):258-65.

149. Saikia B, Suri D, Goel S, Rawat A, Minz RW, Gupta A, et al. Hyper-lgE syndrome with a novel STAT3 mutation-a single center study from India. Asian Pac J Allergy Immunol. 2014;32(4):321-7. doi:10.12932/ ap0456.32.4.2014.

150. Lima AMd, Sperandio VA, Rocha SPd, Ribeiro BMd, Reis CMS. Do you know this syndrome. Anais brasileiros de Dermatologia. 2013:88(5):836-8.

151. Prcic S, Tomić J, Petrović S, Radulović A, Djuran V, Gajinov Z. Recurrent infections and cows-milk hypersensitivity in a 2-year-old girl with hyper immunoglobulin e syndrome. Iran J Allergy Asthma Immunol. 2011;10(4):299-303.

152. Friedrich W, Goldmann SF, Ebell W, Blutters-Sawatzki R, Gaedicke G, Raghavachar A, et al. Severe combined immunodeficiency: treatment by bone marrow transplantation in 15 infants using HLA-haploidentical donors. Eur J Pediatr. 1985;144(2):125-30.

153. Xie L, Hu X, Li Y, Zhang W. Hyper-lgE syndrome with STAT3 mutation: a case report in Mainland China. Clin Dev Immunol. 2010;2010:289.

154. Harville TO, Adams DM, Howard TA, Ware RE. Oligoclonal expansion of CD45RO+T lymphocytes in Omenn syndrome. J Clin Immunol. 1997;17(4):322-32.

155. Sundin M, Tesi B, Böhme MS, Bryceson YT, Pütsep K, Chiang SC, et al. Novel STAT3 mutation causing hyper-lgE syndrome: studies of the clinical course and immunopathology. J Clin Immunol. 2014;34(4):469-77.

156. Villa A, Santagata S, Bozzi F, Giliani S, Frattini A, Imberti L, et al. Partial V(D)J recombination activity leads to Omenn syndrome. Cell. 1998;93(5):885-96.

157. Zhang ZY, Zhao XD, Jiang LP, Liu EM, Cui YX, Wang M, et al. Clinical characteristics and molecular analysis of three Chinese children with Omenn syndrome. Pediatr Allergy Immunol. 2011;22(5):482-7. doi:10.1111/j.1399-3038.2010.01126.x.

158. Engelhardt KR, Gertz ME, Keles S, Schaffer AA, Sigmund EC, Glocker C, et al. The extended clinical phenotype of 64 patients with dedicator 
of cytokinesis 8 deficiency. J Allergy Clin Immunol. 2015. doi:10.1016/j. jaci.2014.12.1945

159. Katugampola RP, Morgan G, Khetan R, Williams N, Blackford S. Omenn's syndrome: lessons from a red baby. Clin Exp Dermatol. 2008;33(4):4258. doi:10.1111/j.1365-2230.2008.02766.x.

160. Gates M, Atkinson T. transient hypereosinophilia and markedly elevated $\operatorname{IgE}$ as the presenting feature in DOCK8 (Dedicator of Cytokinesis 8) Deficiency. J Allergy Clin Immunol. 2012;129(2):159.

161. Ohm-Laursen L, Nielsen C, Fisker N, Lillevang ST, Barington T. Lack of nonfunctional B-cell receptor rearrangements in a patient with normal B cell numbers despite partial RAG1 deficiency and atypical SCID/ Omenn syndrome. J Clin Immunol. 2008;28(5):588-92. doi:10.1007/ s10875-008-9210-7.

162. Wada T, Toma T, Okamoto H, Kasahara Y, Koizumi S, Agematsu K, et al. Oligoclonal expansion of T lymphocytes with multiple second-site mutations leads to Omenn syndrome in a patient with RAG1-deficient severe combined immunodeficiency. Blood. 2005;106(6):2099-101.

163. Kilic SS, Hacimustafaoglu M, Boisson-Dupuis S, Kreins AY, Grant AV Abel L, et al. A patient with tyrosine kinase 2 deficiency without hyper-IgE syndrome. J Pediatr. 2012;160(6):1055-7. doi:10.1016/j. jpeds.2012.01.056.

164. Seki M, Kimura H, Mori A, Shimada A, Yamada Y, Maruyama K, et al. Prominent eosinophilia but less eosinophil activation in a patient with Omenn syndrome. Pediatr Int Soc. 2010;52(4):e196-9. doi:10.1111/j.1442-200X.2010.03135.x.

165. Corneo B, Moshous D, Gungor T, Wulffraat N, Philippet P, Le Deist FL, et al. Identical mutations in RAG1 or RAG2 genes leading to defective $V(D) J$ recombinase activity can cause either T-B-severe combined immune deficiency or Omenn syndrome. Blood. 2001;97(9):2772-6.

166. Tabori U, Mark Z, Amariglio N, Etzioni A, Golan H, Biloray B, et al. Detection of RAG mutations and prenatal diagnosis in families presenting with either T-B- severe combined immunodeficiency or Omenn's syndrome. Clin Genet. 2004;65(4):322-6. doi:10.1111/j.1399-0004.2004.00227.x.

167. Melo KM, Dantas E, De MoraesPinto MI, CondinoNeto A, Gonzalez IG, Mallozi MC, et al. Primary immunodeficiency may be misdiagnosed as cow's milk allergy: seven cases referred to a tertiary pediatric hospital. ISRN Pediatr. 2013;2013:470.

168. Lynch MK, Jones CH, Gaye A, Manteuffel KK. Necrotizing enterocolitis in an infant with Omenn Syndrome. Allergy and asthma proceedings: OceanSide Publications, Inc. 2006.

169. Gennery AR, Slatter MA, Rice J, Hoefsloot LH, Barge D, McLean-Tooke $A$, et al. Mutations in CHD7 in patients with CHARGE syndrome cause $\mathrm{T}-\mathrm{B}+$ natural killer cell + severe combined immune deficiency and may cause Omenn-like syndrome. Clin Exp Immunol. 2008;153(1):7580. doi:10.1111/j.1365-2249.2008.03681.x.
170. Grunebaum E, Bates A, Roifman CM. Omenn syndrome is associated with mutations in DNA ligase IV. J Allergy Clin Immunol. 2008;122(6):1219-20. doi:10.1016/j.jaci.2008.08.031.

171. Peake JE, McCrossin RB, Byrne G, Shepherd R. X-linked immune dysregulation, neonatal insulin dependent diabetes, and intractable diarrhoea. Arch Dis Child Fetal Neonatal Ed. 1996;74(3):F195-9.

172. Giliani S, Bonfim C, de Saint Basile G, Lanzi G, Brousse N, Koliski A, et al. Omenn syndrome in an infant with IL7RA gene mutation. J Pediatr. 2006;148(2):272-4. doi:10.1016/j.jpeds.2005.10.004

173. Ferguson PJ, Blanton SH, Saulsbury FT, McDuffie MJ, Lemahieu V, Gastier $\mathrm{JM}$, et al. Manifestations and linkage analysis in X-linked autoimmunityimmunodeficiency syndrome. Am J Med Genet. 2000;90(5):390-7.

174. Shibata F, Toma T, Wada T, Inoue M, Tone Y, Ohta K, et al. Skin infiltration of CD56(bright) CD16(-) natural killer cells in a case of X-SCID with Omenn syndrome-like manifestations. Eur J Haematol. 2007;79(1):81-5. doi:10.1111/j.1600-0609.2007.00874.x

175. Lucas KG, Ungar D, Comito M, Groh B. Epstein Barr virus induced lymphoma in a child with IPEX syndrome. Pediatr Blood Cancer. 2008;50(5):1056-7. doi:10.1002/pbc.21341.

176. Halabi-Tawil M, Ruemmele FM, Fraitag S, Rieux-Laucat F, Neven B, Brousse N, et al. Cutaneous manifestations of immune dysregulation, polyendocrinopathy, enteropathy, X-linked (IPEX) syndrome. Br J Dermatol. 2009;160(3):645-51. doi:10.1111/j.1365-2133.2008.08835.x.

177. Snover DC, Frizzera G, Spector BD, Perry GS 3rd, Kersey JH. WiskottAldrich syndrome: histopathologic findings in the lymph nodes and spleens of 15 patients. Hum Pathol. 1981;12(9):821-31.

178. Aspinall Al, Pinto A, Auer IA, Bridges P, Luider J, Dimnik L, et al. Identification of new Fas mutations in a patient with autoimmune lymphoproliferative syndrome (ALPS) and eosinophilia. Blood Cells Mol Dis. 1999;25(3-4):227-38.

179. Torbiak RP, Dent PB, Cockshott WP. NOMID-a neonatal syndrome of multisystem inflammation. Skeletal Radiol. 1989;18(5):359-64.

180. Stojanov S, Weiss M, Lohse P, Belohradsky BH. A novel CIAS1 mutation and plasma/cerebrospinal fluid cytokine profile in a German patient with neonatal-onset multisystem inflammatory disease responsive to methotrexate therapy. Pediatrics. 2004;114(1):e124-7.

181. Baehner RL, Johnston RB Jr. Monocyte function in children with neutropenia and chronic infections. Blood. 1972;40(1):31-41.

182. Rezaei N, Moin M, Pourpak Z, Ramyar A, Izadyar M, Chavoshzadeh $Z$, et al. The clinical, immunohematological, and molecular study of Iranian patients with severe congenital neutropenia. J Clin Immunol. 2007:27(5):525-33. doi:10.1007/s10875-007-9106-y.

183. Takahashi N, Kondo T, Fukuta M, Takemoto A, Takami Y, Sato M, et al. Selective IgA deficiency mimicking Churg-Strauss syndrome and hypereosinophilic syndrome: a case report. Nagoya J Med Sci. 2013:75(1-2):139-46.

\section{Submit your next manuscript to BioMed Central and we will help you at every step:}

- We accept pre-submission inquiries

- Our selector tool helps you to find the most relevant journal

- We provide round the clock customer support

- Convenient online submission

- Thorough peer review

- Inclusion in PubMed and all major indexing services

- Maximum visibility for your research

Submit your manuscript at www.biomedcentral.com/submit 